\title{
Persistence of Human Papillomavirus DNA in Cervical Lesions After Treatment With Diathermic Large Loop Excision
}

\author{
A.L. Distéfano, ${ }^{1 *}$ M.A. Picconi, ${ }^{1}$ L.V. Alonio, ${ }^{1}$ D. Dalbert, ${ }^{2}$ \\ J. Mural, ${ }^{2}$ O. Bartt, ${ }^{2}$ G. Bazán, ${ }^{2}$ G. Cervantes, ${ }^{3,4}$ M. Lizano, ${ }^{3,4}$ \\ A.G. Carrancá, ${ }^{3,4}$ and A. Teyssié ${ }^{1}$ \\ ${ }^{1}$ Departamento Virología, Instituto Nacional de Enfermedades Infecciosas, ANLIS Dr. Carlos G. \\ Malbrán, Buenos Aires, Argentina \\ ${ }^{2}$ Hospital Nacional Prof. Alejandro Posadas, Haedo, Argentina \\ ${ }^{3}$ Departamento Biología Molecular, Instituto de Investigaciones Biomédicas, UNAM, DF, México \\ ${ }^{4}$ División de Investigación, Instituto Nacional de Cancerología, DF, México
}

\begin{abstract}
Objective: The aim of this study was to identify human papillomavirus (HPV) in cervical intraepithelial neoplasia (CIN) lesions and to evaluate the persistence of viral DNA after diathermic large loop excision (DLLE) treatment.

Study Design: Biopsies from 36 patients with low- and high-grade CIN lesions were studied before and after DLLE treatment looking for HPV sequences. DNA was extracted to perform a radioactive polymerase chain reaction (PCR) using GP 5,6 generic primers. PCR products were analyzed by the single-stranded conformational polymorphism (SSCP) which is a simultaneous detection and typing method. Dot-blot hybridization with generic and type-specific biotinylated oligonucleotide probes was applied in some cases.

Results: HPV DNA was found in all pretreatment samples, and the viral type was identified in $80 \%$ of them, HPV 16 being the most prevalent. The viral type coincided with that detected in the first biopsy in all except one case. Seventy five percent of the patients (27 cases) were negative for CIN at follow up, but $50 \%$ of them remained HPV DNA positive.

Conclusion: DLLE treatment was effective in removing the CIN lesion but not the HPV. This fact points out the need to asses the presence of HPV in DNA during the follow-up, since viral persistence has been considered a high risk factor for recurrence and/or malignant transformation. Infect. Dis. Obstet. Gynecol. 6:214-219, 1998. @ @ 1998 Wiley-Liss, Inc.
\end{abstract}

KEY WORDS

persistent HPV infection; cervix; therapy; follow-up

$\mathrm{T}$ he notion that a sexually transmitted agent is involved in the pathogenesis of cervical cancer has been considered since the end of the past century. Several epidemiological studies have strongly supported this assumption, while molecular techniques have indicated that certain human papillomavirus (HPV) types are present in the majority of cervical carcinomas, highlighting the contribution

Grant Sponsor: CONACYT; Grant number: 1705-M9209; Grant sponsor: PAPIIT-UNAM; Grant number: IN211394; and Fundación Mosoteguy.

This project was reviewed and approved by the Scientific Committee of our institutions. Informed consent was obtained from subjects.

*Correspondence to: Dr. Angélica L. Distéfano, Departamento Virología, Instituto Nacional de Enfermedades Infecciosas, ANLIS Dr. Carlos G. Malbrán, Avenida Vélez Sársfield 563, (1281) Buenos Aires, Argentina.

E-mail: oncovir@sudnet.com.ar 
of these viruses to the carcinogenesis of the uterine cervix. $^{1-4}$

Among HPV types that infect the genital tract, types 16, 18, 31 and 33 are usually associated with cervical carcinomas ("high-risk" types). A different subset of HPV types, such as 6 and 11, are related to benign cervical lesions ("low-risk" types).

Different techniques are currently available for the treatment of cervical intraepithelial neoplasia (CIN) lesions. These methods are either destructive or excisional, and the application generally depends on the location, the severity of the lesion, and the age of the patient. ${ }^{5}$ The diathermic large loop excision (DLLE) treatment applied to CIN and HPV lesions is a local and ambulatory method that, like the cone biopsy, allows histologic confirmation of the diagnosis. This method is more conservative than conization, a fact that can be very important, especially if lesions are found in women of reproductive age.

Persistence of viral DNA after treatment of CIN lesions is an issue that has not yet been fully studied, especially when high-risk HPV types like HPV 16 and 18 are present.

The presence of HPV DNA in clinical specimens has been determined mainly by Southern blot, ${ }^{6}$ dot blot, ${ }^{7}$ in situ hybridization, ${ }^{8}$ polymerase chain reaction (PCR), ${ }^{9-11}$ and hybrid capture system. ${ }^{12,13}$ The use of PCR has enhanced the sensitivity of detection and has contributed to the increased identification of HPV in cervical lesions. ${ }^{4,14,15}$

One of the most sensitive methods for detecting minor structural alterations of DNA, including point mutations, is single-stranded conformational polymorphism analysis (SSCP) ${ }^{16}$ with previous amplification by PCR. Single base substitutions that produce conformational changes of denatured DNA chains are detected as a mobility shift in polyacrylamide gels under nondenaturing conditions. This method has been recently applied to HPV detection, providing information about the viral type amplified. ${ }^{17}$

In this study, we analyzed the presence of HPV DNA by SSGP-PGR in different cervical lesions, before and after DLLE treatment, and its correlation with the clinical evolution of the cervical lesions.

\section{SUBJECTS AND METHODS Study Group}

Thirty-six patients with ages ranging from 17 to 45 years (mean, 31 years) were included in the study. Five cases of CIN I, five of CIN II and 26 of CIN III showing colpohistologic signs of HPV infection $^{18}$ were selected for DLLE treatment.

\section{Inclusion Criteria for DLLE Treatment}

Women with cervical condylomatous and CIN lesions, noted with colposcopic visualization of the whole atypical lesion, both negative cytobrush and endocervical curettage in CIN II to CIN III. Patients with large ectocervical lesions (more than $1 / 3$ external), pregnant women, and those with difficulties in the follow up were excluded.

\section{Surgical and Histopathological Criteria for DLLE}

It was performed a conservative resection with safety margins employing the therapeutic sufficient criterion in the same way as in the bistoury cone. ${ }^{19}$

Two biopsies were taken from each patient, one before and the other 6-12 months after therapy. The second biopsy was taken from the DLLE site in the areas of irregular or atypical reepithelization. Specimens were fixed and paraffin-embedded for histopathologic and virologic studies.

\section{Lesion Evolution Criteria}

- Negative follow-up: Disappearance of the CIN lesion or presence of minor histologic signs (dystrophy, dyskeratosis, hyper- and parakeratosis, squamous metaplasia, etc.) after therapy.

- Persistence: Presence of lesion of the same grade.

- Progression: Presence of a CIN lesion of a higher grade than that found at the first histologic examination.

\section{DNA Isolation and PCR Amplification}

DNA was extracted and purified from paraffinembedded biopsies as previously described. ${ }^{17}$ Specimens were tested by PCR for $\beta$-globin gene to confirm the presence of adequate human DNA in the sample. ${ }^{20}$

We used PCR reactions with GP5,6 generic primers that amplify a fragment of approximately 
$140 \mathrm{bp}$ from the $\mathrm{L} 1$ region. ${ }^{14}$ As positive controls, cloned DNA from HPV types 6, 11, 16, 18, 31, and 33 (kindly provided by H. zur Hausen, A. Lörincz, and G. Orth) were included in all assays. The PCR reactions were carried out in $10 \mu$ l of solution containing 100-250 ng of DNA, $10 \mathrm{mM}$ Tris $\mathrm{HCl}(\mathrm{pH}$

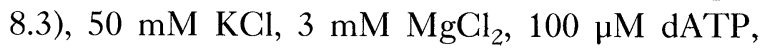
dC'TP and dTTP, $10 \mu \mathrm{M}$ dC'TP and $0.1 \mu \mathrm{L} \alpha{ }^{32} \mathrm{P}$ dCTP $10 \mathrm{mCi} / \mathrm{mL}$ (Dupont ${ }^{\mathrm{TM}}$ ), 10 pmol of each primer and $5 \mathrm{U}$ of AmpliTaq $(5 \mathrm{U} / \mu \mathrm{L}$; Perkin Elmer $\left.^{\mathrm{TM}}\right)$. Forty cycles of amplifications were performed in a Perkin Elmer GeneAmp 9600 thermocycler, $\left(94^{\circ} \mathrm{C}, 30 \mathrm{sec} ; 45^{\circ} \mathrm{C}, 30 \mathrm{sec} ; 72^{\circ} \mathrm{C}, 30 \mathrm{sec}\right)$.

For dot-blot analysis, $50 \mu \mathrm{L}$ final volume of PCR was performed as described above. Nonradioactive dNTPs and MY09,11 consensus primers that generate a 450 -bp fragment of the $\mathrm{L} 1$ region were used. ${ }^{9}$

\section{SSCP Analysis}

Aliquots from PCR were diluted 1:25 with $0.1 \%$ SDS and $10 \mathrm{mM}$ EDTA; then $2 \mu \mathrm{L}$ of them were mixed with equal volumes of stop solution $(95 \%$ formamide, $20 \mathrm{mM}$ EDTA, $0.05 \%$ bromophenol blue, $0.05 \%$ xylene cyanol) and boiled for $5 \mathrm{~min}$. Another aliquot from PCR was diluted 1:25 in TE and mixed with equal volume of blue dye in glycerol. One microliter of diluted samples was loaded on $6 \%$ polyacrylamide gels containing $10 \%$ glycerol and run at $4 \mathrm{~W}$ for $20 \mathrm{hr}$ at room temperature. The gels were fixed with $10 \%$ acetic acid, dried, and autoradiographed using X-OMAT-AR Kodak ${ }^{\mathrm{TM}}$ films, with intensifying screen, at $-70^{\circ} \mathrm{C}$.

\section{Dot-Blot Hybridization}

Samples that could not be typified by SSCP-PCR were reanalyzed by dot-blot hybridization. Denaturation and blotting of the PCR products were performed by conventional methods. ${ }^{21}$ Generic L1 probes were synthesized, and the hybridization was performed as described previously. ${ }^{22}$ MY12, MY13, MY14, WD74 and MY16 biotin-labeled oligonucleotides were applied as type-specific probes for HPV 6, 11, 16, 18, and 33, respectively. ${ }^{9}$

Aliquots $(40 \mu \mathrm{L})$ resulting from PCR were denatured with $20 \mu \mathrm{L}$ of $1 \mathrm{~N} \mathrm{NaOH}$ and blotted to Zeta probe $\left(\mathrm{BioRad}^{\mathrm{TM}}\right)$ membranes. Positive and negative controls were included in each assay. Hybridization was performed at $55^{\circ} \mathrm{C}$ for $3 \mathrm{hr}$. For
TABLE I. Pretreatment histology and clinical evolution after DLLE

\begin{tabular}{lccl}
\hline Histology & $\mathrm{N}$ & $\begin{array}{c}\text { Negative } \\
\text { follow-up }\end{array}$ & $\begin{array}{c}\text { Persistent } \\
\text { cases }\end{array}$ \\
\hline CIN I & 5 & 4 & 1 \\
CIN II & 5 & 3 & 2 \\
CIN III & 26 & 20 & $6^{\mathrm{a}}$ \\
Total (\%) & $36(100)$ & $27(75)$ & $9(25)$ \\
\hline
\end{tabular}

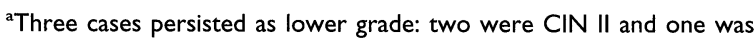
CIN I.

oligonucleotides MY12, 13, and 16, filters were washed twice at $56^{\circ} \mathrm{C}$ for $10 \mathrm{~min}$. For oligonucleotides MY14 and WD74, filters were washed similarly but at $58^{\circ} \mathrm{C}$. Positive hybridization was developed by chemoluminescence (PhotoGene Nucleic Acid Detection System, BRL ${ }^{\mathrm{TM}}$ ).

\section{RESULTS}

Negative follow up was observed in 27 cases and persistence in nine cases (Table 1). One case of CIN II was found to be CIN III in the posttreatment sample; this observation was not considered as a progression but rather disease that was not detected at the first biopsy. However, in $30 \%$ of negative follow-up cases and $88 \%$ of persisting cases, histologic HPV signs were observed in posttreatment biopsies.

A total of 52 colposcopically-directed biopsies of the cervix were examined for the presence of HPV DNA sequences. All extracted DNA was found adequate for PCR assay (positive for $\beta$-globin gene). The SSCP- PCR analysis allowed us to establish band patterns for each control type of HPV. The typing was made comparing these migration patterns with those observed in cervical samples (Fig. 1). All pretreatment samples were HPV positive. Sixteen cases were found to contain HPV 16; eight cases revealed the presence of HPV 6; two cases showed HPV 33, and HPV types 11, 18, and 31 were found in one case each. In eight positive cases, the HPV type could not be determined by this method, since their patterns did not correspond to any one of the standard controls. However, all of the undetermined cases hybridized with L1 generic probe, corroborating the presence of the virus. Two cases yielded two extra bands that suggested HPV 16 and 18 mixed infections; this possibility was confirmed by dot-blot hybridization. 


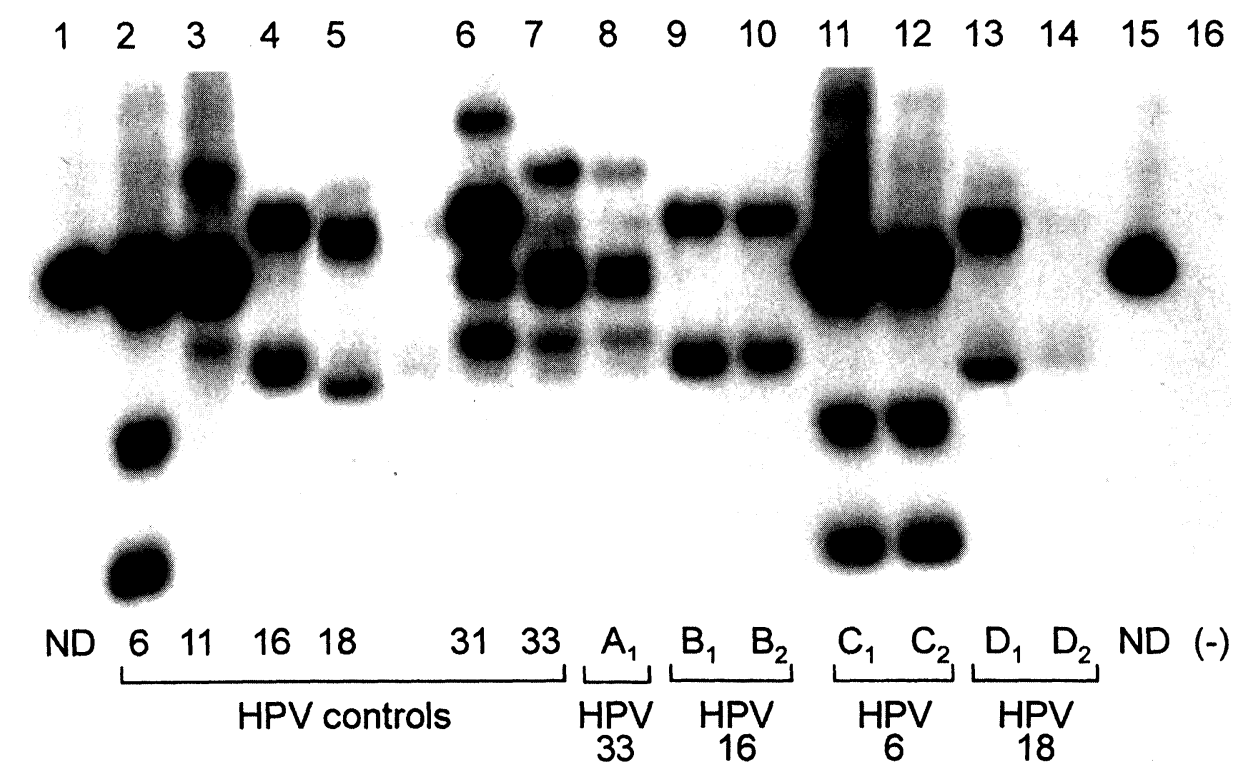

Fig. I. SSCP-PCR analysis of HPV types in CIN lesions before and after DLLE treatment. Genomic DNA was isolated from paraffin-embedded CIN biopsies and subjected to SSCP-PCR analysis using GP5,6 generic primers. PCR products were denatured and electrophoresed on $6 \%$ nondenaturing polyacrylamide gels containing $10 \%$ glycerol, as described in the text. Lanes I and 15: undenatured double-stranded HPV DNA; lanes 2-7: cloned viral DNA corresponding to types 6, 1I, 16, 18, 31 , and 33; lanes 8-I4: viral types found in A, B, C, and D, DNA's patient (the subscripts I and 2 indicate samples taken before and after treatment, respectively); lane 16: negative control (mixed reaction without DNA).

Six cases remained undetermined. Further characterization of these samples was not possible due to the limited amount of the specimen.

Fifty-five percent of posttreatment samples (20 cases) remained HPV-positive; they exhibited the same viral type found in pretreatment samples, except in one case (HPV 6 in the first biopsy and HPV 16 in the second). In 16 posttreatment samples, HPV DNA was not detected; however, eight of these biopsies exhibited persistent histologic signs of viral infection.

Tables 2 and 3 show the HPV distribution in negative follow up and persistent cases after DLLE treatment.

\section{DISCUSSION}

Much effort has been devoted to the early detection and prevention of cervical cancer, and different conservative methods for the treatment of preinvasive lesions have been developed and extensively applied. However, the persistence of HPV infection after treatment and its relationship with the lesion evolution has only recently become an important area of research. ${ }^{23}$

In the present study, we verify the efficacy of DLLE treatment, no matter what viral type was
TABLE 2. HPV in negative follow-up cases after DLLE

\begin{tabular}{|c|c|c|c|c|c|c|c|}
\hline \multirow{2}{*}{$\begin{array}{l}\text { Pretreatment } \\
\text { histology }\end{array}$} & \multicolumn{7}{|c|}{ HPV types ${ }^{a}$} \\
\hline & 6 & II & 16 & 18 & 31 & 33 & $U^{b}$ \\
\hline $\mathrm{CIN} \mathrm{I}(\mathrm{n}=4)$ & $3^{c}(2)$ & - & $1(1)$ & - & - & - & - \\
\hline$C I N \|(n=3)$ & - & - & - & - & - & $I(I)$ & $2(1)$ \\
\hline CIN III $(n=20)$ & $5(2)$ & - & II (5) & $I(0)$ & $\mathrm{I}(0)$ & $\mathrm{I}(\mathrm{I})$ & I (I) \\
\hline
\end{tabular}

aPre- and posttreatment DNA HPV positive cases. The difference between both values corresponds to negative HPV cases after treatment. bUndetermined cases by SSCP-PCR and dot-blot hybridization.

In one case, HPV 6 was detected in the first biopsy and HPV 16 in the second.

involved. A favorable clinical evolution and a high rate of histologic remission was observed in most of the patients during follow-up.

We employed a sensitive SSCP-PCR assay to detect and type HPV DNA and to evaluate the persistence of the virus after DLLE treatment. This methodology allowed us to identify, in a single reaction, several anogenital HPV types, since the pattern obtained for each one was very specific and highly reproducible. This assay let us avoid, in most cases, later restriction enzyme digestion and/ or hybridization.

Some atypical patterns were observed in a limited number of cases that could correspond either to mixed infections, variants of known types, or 
TABLE 3. HPV in persistent cases after DLLE

\begin{tabular}{|c|c|c|c|c|c|c|c|}
\hline \multirow{2}{*}{$\begin{array}{l}\text { Pretreatment } \\
\text { histology }\end{array}$} & \multicolumn{7}{|c|}{ HPV types ${ }^{\mathrm{a}}$} \\
\hline & 6 & 11 & 16 & 18 & 31 & 33 & $\mathrm{UD}^{\mathrm{b}}$ \\
\hline $\operatorname{CIN} I(n=1)$ & - & I (0) & - & - & - & - & - \\
\hline$C I N \|(n=2)$ & - & - & $I(I)^{c}$ & $I(I)^{c}$ & - & - & I (I) \\
\hline CIN III $(n=6)$ & - & - & $4(2)^{c}$ & $I(1)^{c}$ & & & $2(2)$ \\
\hline
\end{tabular}

apre- and posttreatment DNA HPV positive cases. The difference between both values corresponds to negative HPV cases after treatment.

bUndetermined cases by SSCP-PCR and dot-blot hybridization.

'One case showed HPV $16+18$ mixed infection.

different types other than those used as controls. This approach allowed us to successfully determine the viral type in the majority of the samples (78\%). The fact that HPV 16 was the most prevalent type in CIN III lesions corroborated the strong association between this high-risk type and severe lesions.

Using dot-blot hybridization, we were able to identify a mixed infection associated with an undetermined SSCP-PCR pattern. The method allowed us to confirm and extend the results obtained with the SSCP-PCR assay. The few cases that remained undetermined by dot-blot hybridization were CIN III, supporting the necessity of identifying oncogenic HPV types other than 16, 18, 31 , and 33 .

In about half of negative SSCP-PCR cases, histologic HPV signs remained. This fact could indicate that structural modifications of tissues, related to HPV infection, may persist even when the viral DNA is not found. Another possibility is that koilocytosis or cytophatic effects were the possible consequence of other infections. We could not rule out problems associated with the sensitivity of the methodology used, although SSCP-PCR is able to detect less than 10 copies of HPV.

Detection of the same viral type of HPV DNA during the follow up is likely to reflect the persistence of the infection, but the possibility of reinfection with the same virus exists. Development and validation of HPV testing strategies, including the assessment of viral load, would appear increasingly relevant.

Persistence of HPV DNA has been associated with several factors including presence of high-risk types, viral load, age, number of sexual partners, sex hormone regulation, and host immunity. ${ }^{24}$ In this study, persistence of HPV DNA was associated with the presence of HPV 16 as well as HPV 6.
The DLLE treatment proved effective in the eradication of CIN lesions, but seems to fail in eliminating the viral infection. In spite of the negative follow up observed, in half of treated patients, HPV DNA was demonstrated. Several epidemiological studies have indicated that persistently infected women with oncogenic HPV types are more likely to develop cervical neoplastic lesions. ${ }^{25}$ In our treated patients, viral persistence with previous history of severe cervical disease would be considered a greater risk factor of relapse.

These findings highlight the importance of performing follow-up studies over prolonged periods due to the possibility of recurrence and/or malignant conversion of premalignant lesions. Our results emphasize the importance of the virological test to complement the clinical study, improving the diagnostic accuracy and efficiency.

\section{ACKNOWLEDGMENTS}

The authors acknowledge Miriam C. Guido and Joaquín V. González for technical assistance. This work was supported by a collaborative agreement between CONICE'T (Argentina) and CONACYT (México).

\section{REFERENCES}

1. Muñoz N, Bosch FX, Shah KV, et al.: The Epidemiology of Human Papillomavirus and Cervical Cancer. IARC Sci Publ 119:251-261, 1992.

2. Schiffman MH: New epidemiology of human papillomavirus infection and cervical neoplasia. J Natl Cancer Inst 87:1345-1347, 1995.

3. Syrjänen KJ: Human papillomavirus in genital carcinogenesis. Sex Transm Dis 21:886-889, 1994

4. Bosch FX, Manos M, Muñoz N, et al. \& IBSCC Study Group: Prevalence of human papillomavirus in cervical cancer: a worldwide perspective. J Natl Cancer Inst 87: 796-802, 1995.

5. Minucci D, Cinel A, Insacco E: Diathermic loop treatment for CIN and HPV lesions. a follow-up of 130 cases. Eur J Gynecol Oncol 5:385-393, 1991.

6. Lörincz AT: Detection of human papillomavirus infection by nucleic acid by hybridization. Obstet Gynecol Clin North Am 14:451-469, 1987.

7. Melki R, Khoury B, Catalan F: Nucleic acid spot hybridization with non radioactive labeled probes in screening for human papillomavirus DNA sequences. J Med Virol 26:137-143, 1988.

8. Alonio LV, Dalbert D, Mural J, et al.: Different papillomaviruses in uterine cervical lesions: detection and location by "in situ" hybridization with biotinylated probes. The Cervix \& The Low Female Genital Tract. 3:339-346, 1990 . 
9. Manos MM, Ting Y, Wright DK, Lewis AJ, Broker TR, Wolinsky SM: The use of polymerase chain reaction amplification for the detection of genital papillomaviruses. Cancer Cells 7:209-214, 1989.

10. Evander M, Edlund K, Boden E, et al.: Comparison of a one-step and a two-step polymerase chain reaction with degenerate general primers in a population based study of human papillomavirus infection in young Swedish women. J Clin Microbiol 30:987-992, 1992.

11. Bauer HM, Hildesheim A, Schiffman MH, et al.: Determinants of genital HPV infection in low risk women in Portland, Oregon. Sex Transm Dis 20:274278, 1993.

12. Cox J'T, Lorincz AT, Schiffman MH, Sherman ME, Cullen A, Kurman RJ: Human papillomavirus testing by hybrid capture appears to be useful in triaging women with a cytologic diagnosis of atypical squamous cells of undetermined significance. Am J Obstet Gynecol 172: 946-954, 1995.

13. Schiffman MH, Bauer HM, Hoover RN, et al.: Epidemiological evidence showing that human papillomavirus infection causes most cervical intraepithelial neoplasia. J Natl Cancer Inst 85:958-964, 1993.

14. Snijders PJF, van den Brule AJC, Schrijnemakers HJF, Snow G, Meijer CJ, Walboomers JM: The use of general primers in the polymerase chain reaction permits the detection of a broad spectrum of human papillomavirus genotypes. J Gen Virol 71:173-181, 1990.

15. van den Brule AJF, Walboomers JMM, Du Maine M, et al.: Difference in prevalence of human papillomavirus genotypes in cytomorphologically normal cervical smears is associated with a history of cervical intraepithelial neoplasia. Int J Cancer 48:404-408, 1991.

16. Orita $\mathrm{M}$, Iwahana $\mathrm{H}$, Kanazagua $\mathrm{H}$, et al.: Detection of polymorphisms of human DNA by gel electrophoresis as single strand conformation polymorphisms. Proc Natl Acad Sci USA 86:2766-2770, 1989.

17. Lizano M, Berumen J, Guido MC, Casas L, GarcíaCarrancá A: Association between papillomavirus type 18 variants and histopathology of cervical cancer. J Natl Cancer Inst 89:1227-1231, 1997.

18. Reid R, Scalzi P: Genital warts and cervical cancer VII. An improved colposcopic index for differentiating benign papillomaviral infection from high-grade cervical intraepithelial neoplasia. Am J Obstet Gynecol 153:611618, 1985.

19. Mural J, Dalbert D, Bartt O, Baistrochi A: Tratamiento. In Mural J, Teyssié AR, Baistrochi CA, Alfonsín AE (eds): El Virus Papiloma en la Pareja Humana. 1st ed. Buenos Aires: Editorial Ascune Hnos, Inc., pp 147-196, 1993.

20. Bauer HM, Ting Y, Greer CE, et al.: Genital human papilloma virus infection in female university students as determined by a PCR-based method. JAMA 265:472477, 1991.

21. Sambrook J, Fritsch E, Maniatis T: Molecular Cloning. A Laboratory Manual. Cold Spring Harbor, NY: Cold Spring Harbor Laboratory, 1989.

22. Bauer HM, Greer CE, Manos M: Determination of genital human papillomavirus infection by consensus PCR amplification. In Herrington CS, McGree JO (eds): Diagnostic Molecular Pathology: A Practical Approach. Oxford: Oxford University Press, pp 131-152, 1992.

23. Brison J, Bairati I, Morin C, et al.: Determinants of persistent detection of human papillomavirus DNA in the uterine cervix. J Infect Dis 173:794-799, 1996.

24. Keng-Ling Ch, Hjerpe A: Persistence of human papillomavirus (HPV) infections preceding cervical carcinoma. Am Cancer Soc 77:121-127, 1996.

25. Villa L: Human papillomaviruses and cervical cancer. Adv Cancer Res 65:321-341, 1997. 


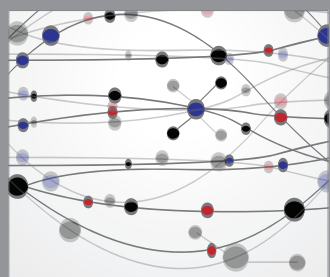

The Scientific World Journal
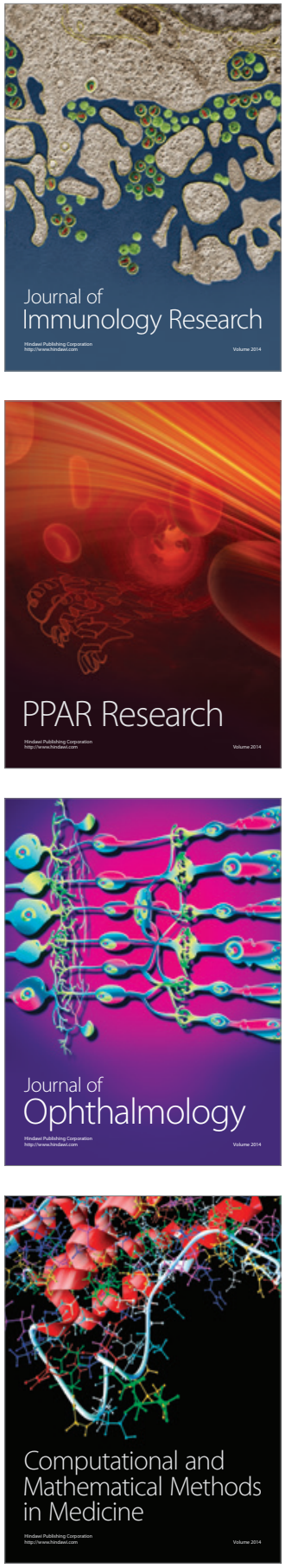

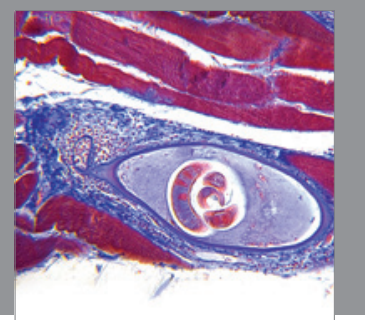

Gastroenterology

Research and Practice
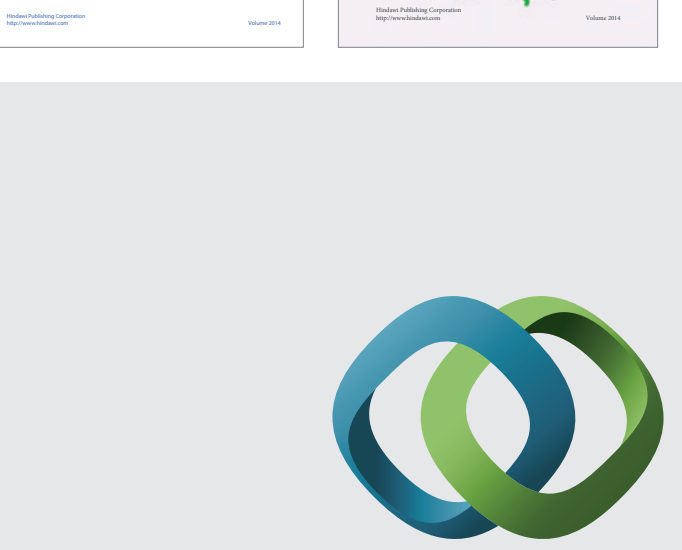

\section{Hindawi}

Submit your manuscripts at

http://www.hindawi.com
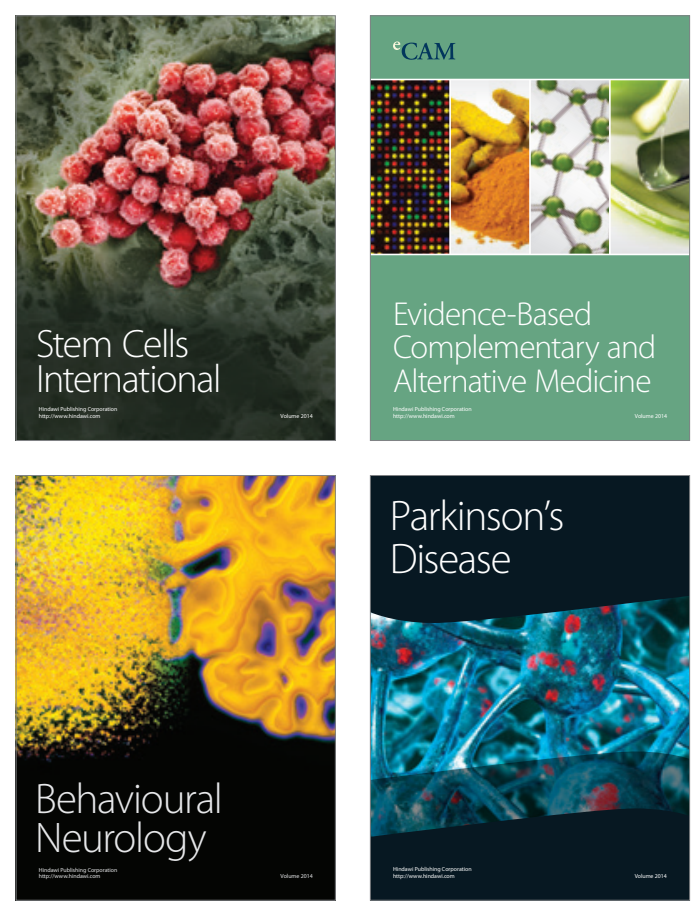

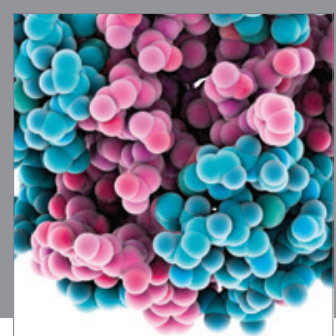

Journal of
Diabetes Research

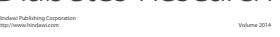

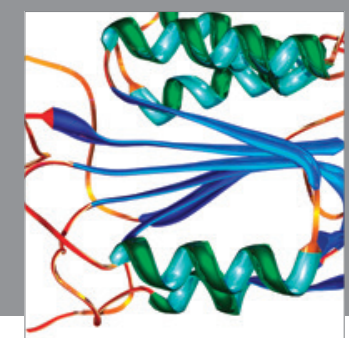

Disease Markers
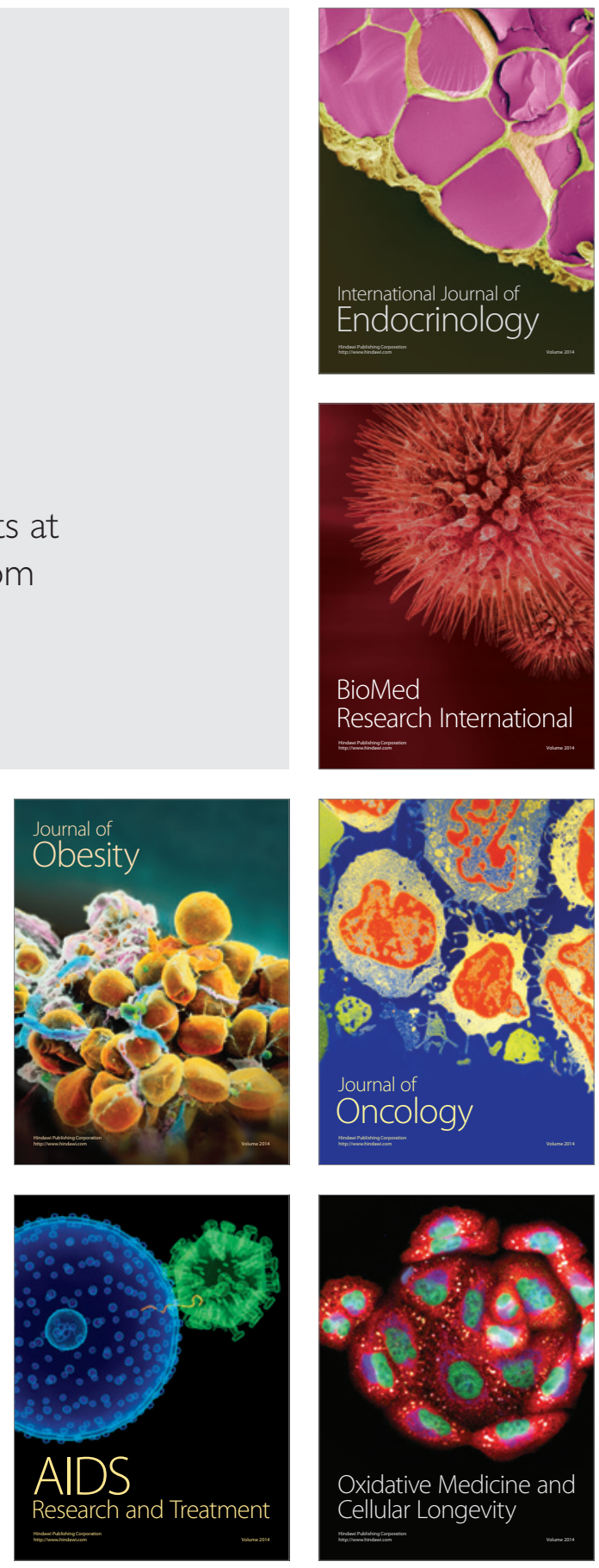